\title{
PUBLIC ECONOMICS AND STARTUP ENTREPRENEURS
}

\author{
ROBIN BOADWAY \\ JEAN-FRANÇOIS TREMBLAY
}

\author{
CESIFO WORKING PAPER NO. 877 \\ CATEGORY 1: PUBLIC FINANCE \\ FEBRUARY 2003
}

Presented at CESifo Conference on Venture CAPITAL, ENTREPRENEURShIP, AND PUBlic Policy, NOVEMBER 2002

\footnotetext{
An electronic version of the paper may be downloaded

- from the SSRN website: www.SSRN.com

- from the CESifo website: www.CESifo.de
} 


\title{
PUBLIC ECONOMICS AND STARTUP ENTREPRENEURS
}

\begin{abstract}
This paper surveys the various forms of market failure that can arise when innovating entrepreneurs consider entering an industry, and outlines possible implications for public policy. Externalities can arise from entrepreneurial activities such as spillover benefits from new innovations and spillover costs on incumbent firms. New entrepreneurs can also face various barriers to entry, either natural ones or those created by incumbent firms or government policy. They may also face problems in obtaining credit at efficient terms if there are information asymmetries in markets for either loan or equity finance. Finally, asymmetric information may also plague new firms in the hiring of workers. These various inefficiencies are of contradictory sign, some calling for an incentive to startup firms and other for the opposite. Thus, public policy is ambiguous and depends on the circumstances at hand.
\end{abstract}

JEL Code: H32, H25.

\author{
Robin Boadway \\ Queen's University \\ Department of Economics \\ Dunning Hall \\ K7L 3 N6 Kingston, Ontario \\ Canada
}

\author{
Jean-François Tremblay \\ Queen's University \\ Department of Economics \\ Dunning Hall \\ K7L 3N6 Kingston, Ontario \\ Canada
}

boadwayr@qed.econ.queensu.ca

We are grateful to conference participants for many comments that were very helpful in preparing this paper. 


\section{Introduction}

This paper focuses on the rationale for government policies targeted to startup entrepreneurs. The emphasis is on possible sources of market failure that apply to new entrepreneurs who are contemplating entry into an industry. The possibility of market failure arises because of the unique characteristics that startup entrepreneurs possess. They typically bring with them innovations of one sort or another — new products, new technologies, new talents, etc. — that may compete with, and even threaten the existence of, existing firms. As such, they may face various obstacles. These range from barriers to entry imposed by existing firms and government policies, to difficulties in appropriating the benefits of the innovations they bring to the market, to uncertainties about their prospects of success, to problems of getting outside finance and hiring new workers. All of these can give rise to market failure, or inefficiencies. The sources of market failure that are particularly relevant are those associated with informational asymmetries, especially those that apply under uncertainty. By their very nature, the characteristics most likely to contribute to the success of new firms are liable to be private rather than public information.

The purpose of this paper is to take a comprehensive look at these sources of market failure. This involves drawing on a variety of literatures, including industrial organization, growth and innovation theory, financial economics and labor economics. Our ultimate objective as public economists is to identify arguments for or against government policy intervention. That turns out not to be a straightforward task since many of the possible sources of market failure that can be identified are specific to the modeling assumptions used, and can work in offsetting directions. We can do little more than catalogue them at this stage. In so doing, it 
should be emphasized that our focus is solely on efficiency rather than equity. There is also a parallel literature on redistributive policies when households can choose to become entrepreneurs rather than workers (e.g., that cited in Boadway, Marchand and Pestieau, 1991).

We begin with a discussion of the externalities that can arise from entrepreneurial activities. Especially important are those that involve various forms of spillovers benefits or costs that can accrue from the entry and from the innovative activities of entrepreneurial firms. For much of this discussion, we draw on the new growth literature, especially the part that emphasizes the creative destruction process whereby there is a continual sequence of firms with new ideas or technology displacing old ones.

Then we turn to various non-financial barriers that entrepreneurs might face when entering an industry. These take three main forms. First, incumbent firms may face natural advantages over new entrants because of the dominant positions they hold in their industry. Second, existing firms might actually take actions that create artificial barriers to entry for new firms. Finally, government policies, especially business tax policies, may inadvertently deter entry by new firms.

The next important class of problems considered concerns those that new firms face when seeking the finance necessary to start a business. These especially arise when creditors do not have perfect information about the quality of entrepreneurs applying for credit. As the literature shows, policy intervention may be welfare improving even if the government is no better informed than the creditors. The nature of credit market failure may differ according to whether new firm financing takes the form of loans or equity finance. We begin our discussion of financing issues by outlining the circumstances under which new firms will be financed by either or both of these forms of finance. For each of these, we then provide a concise survey of 
the problems of asymmetric information in financing startup entrepreneurs, and draw some policy implications. Finally, we consider the special additional problems that arise when new firms are financed by venture capitalists who, in addition to providing finance, also provide managerial advice.

New entrepreneurs not only require finance to purchase capital goods, but also must hire workers. Asymmetric information problems may also characterize the hiring of new workers. New firms may find it more difficult than established firms to gauge the quality and suitability of new workers. This constitutes the final class of problems we consider. We outline the various special problems that new hiring poses for startup firms and consider possible policy responses.

As will be evident from our ensuing discussion, there are a wide variety of inefficiencies that may be associated with entrepreneurs starting up their own firms, and these inefficiencies can be of contradictory sign. Some call for providing an incentive to startup firms, while others suggest the opposite. That implies that policy advice is necessarily ambiguous, and depends on the particular circumstances at hand. All we are able to do is to summarize as many of these as possible in an intuitive and non-technical way and that is our intent.

\section{Externalities of Entrepreneurial Activity}

As Schumpeter (1942) emphasized, entrepreneurship is typically associated with innovating new firms competing with, and ultimately displacing, obsolete existing firms. In order to enter a market successfully, new entrepreneurs will need to introduce a new product to the market or have a cost advantage over established firms in the production of existing products. The process of research to discover new products or processes, and the subsequent decisions to enter, grow and exit an industry can all give rise to externalities that can make entrepreneurial decisions 
inefficient. In this section, we summarize the various externalities that have a particular bearing on the innovation and startup decisions of potential entrepreneurs.

\section{Incentive to Innovate: Private versus Social Value}

Consider first the incentive for a given firm, whether a new firm or an incumbent, to innovate in cost reducing methods of production—so-called process innovations. The amount of resources devoted to innovation may not be socially optimal for a variety of reasons, and these tend to work in opposing directions. We can identify three classes of inefficiency associated with innovating activities.

First, the private value of an innovation to an entrant may differ from its social value because of a business-stealing effect. Potential entrants do not internalize the destruction of rents of established firms. Since rents are of value to society (even if they are monopoly rents), this effect tends to cause entrants to over-value innovations relative to the optimum (Reinganum, 1985; Aghion and Howitt, 1992).

Second, for both established firms and potential entrants, the private value from process innovation tends to be lower than the social value because it does not include the increase in consumer surplus that results from lower production costs. This is the appropriability effect (Arrow, 1962a). Even if the post-innovation product market is competitive and consumer surplus is zero at the margin, total consumer surplus will be higher under lower production costs, and that benefit is not taken into account by firms at the previous stage of research. Therefore, in the absence of perfect price discrimination, firms cannot appropriate the full social gain from innovating, and that will cause them to under-value it. 
Finally, with sequential and cumulative innovations, technological or knowledge spillovers may also distort the optimal allocation of resources devoted to innovation. Because innovation builds on existing technologies, the benefits of research efforts spill over to future researchers. This intertemporal spillover effect (Aghion and Howitt, 1992) is also an appropriability problem, although it refers to the non-appropriability of cost savings rather than consumer surplus. Since innovators do not take into account the spillover benefits of their own research for future innovators, this distortion tends to make the level of innovation effort lower than optimal (see also Romer, 1990).

Taken together, these effects suggest that the social value of innovative activity unambiguously exceeds the private value for existing firms. But the case is not so clear for new firms because of the offsetting business-stealing effect. One might be led to suppose that policies should provide a greater incentive for existing firms to innovate than for new firms.

\section{Investment in Innovation: Rent-Seeking}

Additional considerations arise when the possibility exists of several new firms vying for new innovations. In the extreme case, potential entrepreneurs may compete in research effort to be the first to find a given innovation (Futia, 1980; Rogerson, 1982). Suppose competition takes the form of a contest in which the probability of being the successful innovator depends on the relative level of research investment. As is standard in contest models, there is too much entry into the research contest, and each participant invests too much. With free entry of identical innovators, the rents of the innovation can be virtually dissipated by the investment costs. Tremblay (2002b) has developed a dynamic version of rent-seeking in which the optimal time at which to devote resources to the development of a new production process to replace the existing one is determined by the exogenous growth of basic scientific knowledge in the economy. 
Because of rent-seeking by venture capitalists, innovation and the entry of new firms tends to occur too soon relative to the social optimum.

This type of rent dissipation problem has also been shown to arise in auction-type models of innovation (Dasgupta and Stiglitz, 1980). More innovative effort leads to earlier innovation. The firm that commits the highest level of resources to innovation is sure to be the first to succeed, and is the only one to innovate. In equilibrium, only the winning firm expends any resources, and as in an auction, the value of the winning 'bid' is the value of the innovation. The entire social surplus is dissipated: too much is spent on research and innovation occurs too early.

\section{Entry and Investment: Learning by Doing}

Improvements in productivity may come not only from expenditures on innovation but also from the experience of working with existing technologies. As firms increase their capital stock, they simultaneously learn how to be more productive (Arrow, 1962b; Kaldor and Mirrlees, 1962; Romer, 1986), and that learning may spill over to other industries. Therefore, the cumulation of past experience or investment generates cost reductions that benefit future firms. Since current firms do not appropriate these benefits, there is too little investment, whether by old or new firms.

In the model of Jovanovich and Lach (1989), learning-by-doing and technological progress are directly tied to the entry of new firms in the industry. Firms have vintage-specific cost structures. As entry and investment proceed in the industry, costs decrease due to learningby-doing. New entrants benefit from past experience reflected in the technology they are able to adopt when they enter. But, firms do not appropriate the cost reductions that arise from the learning experience resulting from their own entry decisions. These benefits spill over to future entrants. Delaying entry allows firms to benefit from additional industry investment and 
experience. But, since the price of output decreases with total entry, firms can enjoy higher prices by entering early. In equilibrium, entry proceeds too slowly relative to the optimum, because firms do not internalize the learning benefit of their own entry. In this context, policies that speed up entry would be welfare improving.

\section{Product Differentiation and Entry}

The above discussion has focused on innovations that reduce the costs of producing a given product. But, similar distortions may apply in markets with differentiated products where entry involves producing a new product. In the monopolistic competition models of Dixit and Stiglitz (1977) and Spence (1976), offsetting effects may lead to too few or too many entrants and product diversity. On the one hand, entry and product diversity tend to be too high because of a trade diversion effect similar to the business-stealing effect discussed above. By introducing a new product to the market, a firm diverts some consumers from other firms. Given that prices exceed marginal costs under monopolistic competition, this implies a reduction in social benefit. Because of this negative externality, there is too much product diversity in equilibrium. But at the same time, there is also a distortion in the opposite direction because of the nonappropriability of consumer surplus. Firms do not take into account the increase in consumer surplus that results from more diversity. The relative magnitudes of these effects depend on the

extent of competition in the market. For example, Salop (1979) constructs an oligopoly (spatial competition) model with differentiated goods and free entry. In his model, the trade diversity effect turns out to dominate the non-appropriability effect, so entry is excessive. But this depends on the specifics of the model.

In markets with differentiated products, there may be costs associated with the need to advertise a product to make consumers aware of its existence and characteristics. Grossman and 
Shapiro (1984) extend the excessive product diversity result of Salop (1979) to a model with imperfect information and informative advertising. As advertising by firms increases, consumers have better knowledge of the products available and can consume products that better matches their preferences. Grossman and Shapiro show that in the free-entry equilibrium there is still too much entry (diversity), but firms tend to advertise too little relative to the optimum.

\section{Information Externalities of Entry}

Entry into a new activity may signal to other potential entrants that the activity is a profitable one, thereby inducing them to enter and compete away some of the profits. To the extent that acquiring this informative signal is costly to the first entrant, entry will be too slow (AlexanderCook, Bernhardt, Roberts, 1998). In effect, the entry decision is analogous to a game of chicken, or a 'best-shot' public good. The first entrant must incur the cost to acquire the information about the profitability of various sorts of activity, and this immediately becomes available to mimickers once the initial entrant has revealed the activity by its own actions.

\section{Location of New Firms: Agglomeration Externalities}

Finally, new firms can generate agglomeration externalities for other firms in the same location (Souberyan and Thisse, 1999; Ottaviano and Thisse, 2000; Fujita and Thisse, 2001). These can be due to knowledge spillovers, improvements in labor market pooling and matching, the lowering of transportation costs, and network externalities with respect to supplies. Unlike with the previous externalities, this calls as much for coordination of location decisions among firms (e.g. creation of industrial clusters) as it does for incentives to enter or not. In any case, it is not clear that the problem of agglomeration externalities is any more important for new firms than for existing ones. On the contrary, large firms may have more discretion in choosing locations 
for their plants than new firms do. The latter may be restricted to the place of residence of the entrepreneur.

\section{Barriers to Entry}

Even in the absence of any externalities associated with new firms, entry decisions might be inefficient because of artificial entry barriers that exist. These barriers might arise simply from advantages that incumbent firms have relative to new entrants. Alternatively, incumbent firms might erect the barriers precisely to deter new entrants. Or, barriers might exist because of government policies that incidentally deter new firms from entering. These three categories of barriers to entry are considered in this section. In the following section, inefficiencies of entry that arise from imperfect information in credit markets are considered.

\section{Incentive to Innovate: Potential Entrants versus Incumbents}

To begin with, let us examine the innovation incentives of potential entrants relative to those of established firms. This issue has received considerable attention in the literature. Consider process innovations that reduce the cost of producing a given product. There are two offsetting influences at work - a replacement effect, which favors new entrants, and an efficiency effect, which favors incumbents.

The replacement effect, which is analogous to the business-stealing effect discussed above, occurs when the incentive of existing firms to undertake research are muted by the fact that the innovation will destroy the firms' own monopolistic rents (Arrow, 1962a). For example, if the timing of an innovation—or whether an innovation occurs at all—is uncertain and depends on the amount of resources devoted to research, an increase in innovative effort by an incumbent 
monopolist will contribute to an increased chance of obtaining an innovation that reduces the costs of production. But at the same time, this increases the probability of destroying the monopoly rents it would otherwise already have earned. Potential entrants do not face this tradeoff, so tend to have a higher incentive to undertake innovate activity than current incumbents.

On the other hand, to the extent that the innovation is likely to occur in any case, a firm that initially has a monopoly in the product market has a greater incentive to innovate than potential entrants, as long as innovations are not drastic (that is, do not displace all competitors). As Gilbert and Newbery (1982) argued, the value of innovating to the potential entrant is the stream of duopoly profits that the entrant would receive when competing with the current monopoly. On the other hand, the monopolist's gain from innovating is the difference between the monopoly profits that would result from the use of the new technology and the duopoly profits, given that if he does not innovate, the entrant will. Since monopoly profits are always larger than the sum of duopoly profits of the two firms, the value of the innovation to the current monopolist is necessarily larger than the value to a new entrant. This is the efficiency effect by which dominant positions in the product market tend to persist.

When the innovation process is stochastic, whether innovation is more likely to be done by new firms or incumbents will depend on which of the replacement and efficiency effects dominates. The more competitive is the market to begin with, the smaller is the replacement effect. Also, the larger innovations are, the weaker is competition in the post-innovation market. Consequently, the efficiency effect is relatively small. In the extreme case of drastic innovations, firms initially established in the market are completely driven out by the innovation, and there is no efficiency effect (Reinganum, 1983). In this case, there is a strong tendency towards entry, and innovation and entrepreneurship are closely related. By the same token, if the 
innovation is going to occur for certain by either the incumbent or an entrant, there is no replacement effect since the monopoly profits would have been lost anyway.

Since post-innovation monopoly profits are larger than the sum of duopoly profits in the case of non-drastic innovations, new innovating firms may have strong incentives to cooperate with the incumbent at the commercialization stage. Gans, Hsu and Stern (2002) model the commercialization strategy of innovators who choose between entering the product market (competitive strategy) and cooperating with incumbents via licensing, alliances or acquisition (cooperative strategy). Search and bargaining costs and the strength of intellectual property protection are factors that determine whether innovators compete or cooperate with incumbents. High bargaining costs and weak protection of intellectual property are forms of failures in the market for ideas that favor technology adoption through entry. With weak intellectual property rights, innovators that wish to cooperate with an established firm face the risk of expropriation, since the innovator would typically need to disclose its idea at the bargaining stage. Benefits from a cooperative strategy include avoiding competition and limiting duplicative investments. Gans, Hsu and Stern provide empirical evidence that innovators who possess intellectual property and who are associated with venture capitalists (which is argued to reduce search and bargaining costs) are more likely to cooperate with incumbents.

The various externalities outlined in the previous section imply an efficiency role for public policy. The appropriate policies required to restore efficiency, and whether these policies should be targeted particularly at established firms or potential entrants, depends on the specific characteristics of the innovation process and on the innovation incentives of potential entrants relative to those of established firms. For example, in a market where innovations are typically large, but R\&D outcomes highly stochastic, the replacement effect and the business-stealing 
distortion would tend to dominate. Therefore, innovations would tend to occur too often and would typically be introduced by new firms. In this case, the appropriate policy might be to lower the innovation incentives of potential entrants.

\section{Entry Deterrence by Incumbents}

The classic method of deterring entry is for established firms to undertake excessive investments. By building a large production capacity, firms can credibly commit to driving the price down by producing at high levels following the entry of a competitor (Spence, 1977; Dixit, 1980; Fudenberg and Tirole, 1983). With this type of strategic investment, policies that increase the cost of capital of established firms could potentially stimulate entrepreneurship. In a variant to this, Eaton and Lipsey (1981) show that investments in highly durable capital can deter entry. This allows firms to commit to competing with future entrants longer. In this case, the depreciation provisions of the business tax systems may be designed to counter the strategic behavior of established firms and facilitate entry.

Advertising may also be used for the purpose of entry deterrence. As argued by Baldani and Masson (1984), pre-entry advertising by established firms can create loyalty among consumers, which would reduce an entrant's revenues for any level of its own advertising. However, as shown by Schmalensee (1983), the loyalty of consumers may also lead to a less aggressive price response by the incumbent following entry, thereby muting the barrier imposed on new entrants.

Patenting offers another strategy that may be used by established firms to prevent the entry of new firms (Gilbert and Newbery, 1982). If incumbents have greater incentives to innovate than new entrants, they might invest more on $\mathrm{R} \& \mathrm{D}$ and achieve an innovation earlier. To protect rents, a monopolist may even acquire the property rights on a technology without ever 
using it in production. Similarly, a monopolist may obtain a patent for a new product, which is not sufficiently differentiated to be worth introducing in the market (from the monopolist's perspective).

Tremblay (2002a) examines the entry deterrence behavior of established firms in a dynamic creative destruction model where entrants replace existing firms by adopting new technologies. The exogenous growth of the relative cost of labor drives the sequential entry of firms who will be using more capital-intensive technologies (Kennedy, 1964; Atkinson and Stiglitz, 1969). Since capital is vintage specific, new entrants have a cost advantage over established firms, and entry induces exit from the market. In fact, because of the initial investment cost and the freedom of entry, entry is only profitable in equilibrium if it induces exit from the market. In this context, established firms have incentives to over-invest in order to delay the entry of innovating firms. Business tax systems that lower the return to capital or that encourage exit can be welfare improving.

\section{Tax Policy as a Barrier to Entry}

The structure of many business tax systems implicitly discriminates against startup firms. The main reason is the absence of loss offsetting or refundability provisions. Startup firms are typically in a loss position for some time, and if they cannot fully refund those losses, this increases their costs and puts them at a disadvantage. Established firms can more readily offset the costs of new investments against revenues elsewhere in the firm. This is exacerbated by the fact that startup firms typically face significant risks on their new investments. These costs of risk can typically not be written off in the tax system (at least unless cash flow taxation with full loss offsetting is used). In addition to being able to offset losses better, established firms are also better able to diversify their risks against other investments in the firm. 
There are further tax problems faced by startup firms. Many tax systems have various forms of profit-insensitive taxes, such as employer payroll taxes, capital taxes and property taxes. These may impose more of a burden on new firms than on established ones. Business taxes may also discriminate against outside versus inside equity finance as a result of the so-called trapped equity effect. That is, new equity issues incur liability for dividend taxation, whereas investment financed out of retained earnings effectively shelters the investment from dividend taxation liabilities that are already incurred (Auerbach, 1983). This problem is mitigated to the extent that capital gains are effectively taxed at a similar rate to dividends.

Gordon (1998) argues, however, that the combined personal-corporate tax system can actually favor startup entrepreneurs. If the tax rate on personal income is higher than the tax rate on corporate income, there are incentives to reclassify earnings as corporate rather than personal. Corporate employees can achieve this by receiving part of their compensation as stock options, for example. However, because of restrictions in tax laws about equity compensation and various non-tax costs, income shifting may be more difficult for corporate employees than for entrepreneurs. Non-tax costs can arise, for instance, because of liquidity constraints, risk associated with equity compensation and asymmetric information about the true value of a firm's equity. Then, if the difference between corporate and personal tax rates is sufficiently large, there may be strong incentives to exploit an idea or a new product by becoming an entrepreneur rather than as a corporate employee.

The literature on the political economy of capital taxation has emphasized a further problem that might have a bearing on new firms, the so-called capital levy (or hold-up) problem. Because of an inability to commit to future tax rates, governments find it difficult to avoid setting taxes on capital excessively high to tax capital already invested. Since it is hard to 
discriminate in favor of new capital, new investment is affected as well. This discriminates against entry, especially if new firms are more capital-intensive, although this can be mitigated by up-front investment incentives (Vigneault, 1996; Wen, 1997).

As Marceau and Smart (2002) argue, political lobbying might also mitigate the capital levy problem. They propose a common agency model in which firms first announce their investment plans and then lobby politicians to receive preferential tax treatment. After tax rates are determined, firms must incur industry-specific adjustment costs if they wish to change their investment level. The possibility of lobbying is shown to make tax rates less sensitive to adjustment costs, and may even reverse the capital levy problem: industries with high adjustment costs may lobby so much that their tax rates end up being lower, in equilibrium, than those of more flexible industries. Nonetheless, industries with higher adjustment costs still invest less than more flexible industries, since the cost of lobbying acts as a deterrent to investment. New entry into industries that rely on sunk capital might well be facilitated by the intense lobbying by the owners of old capital in those same industries. At the same time, startup firms in new areas of activity may be less able to participate in lobby groups (which require organization) and that puts them at a tax disadvantage.

The empirical evidence of the effects of taxation on entrepreneurial activity is mixed. Using US individual tax return data, Berry Cullen and Gordon (2002) find that reductions in personal income tax rates lower entrepreneurial activity. In order to offset losses against other personal income, entrepreneurs choose to be unincorporated initially when making losses. To benefit from lower corporate tax rates, they incorporate when the firm generates profits. Given that firms have the option to incorporate, lower personal tax rates discourages risk taking and entrepreneurship by decreasing tax deductions in the case of losses. High personal income tax 
rates also stimulate entrepreneurship for the purpose of reclassifying employment income into corporate income.

In contrast, Rosen (2002) reports empirical results according to which higher personal tax rates induce entrepreneurs to expand their businesses more slowly, lower capital investment and reduce the probability that workers are hired. Gentry and Hubbard (2001) show empirically that the level of marginal tax rates has no effect on self-employment but that progressive marginal tax rates lower entry into self-employment and business ownership.

\section{Financing Issues}

Entrepreneurs typically require outside finance in order to start new firms. Since the firms are new, investors are likely to have less information about the prospects for success than the entrepreneurs themselves. In particular, suppose that the quality of an entrepreneur's project is private information to him, while investors know only the distribution of entrepreneurs by quality. This asymmetric information leads to the possibility of credit market failure in which the number and/or the quality of firms able to obtain finance is inefficient. To focus on credit market failure in the starkest way, simple models are typically used. The commonly used benchmark case is one in which entrepreneurs differ only in the quality of their project (Jaffee and Russell, 1976; Stiglitz and Weiss, 1981). Projects succeed with a probability $p$ and offer a return $R$; if they do not succeed, they yield a low return, zero for simplicity. The quality of a project is reflected in its $(p, R)$ combination. Entrepreneurs are risk-neutral and are passive in the sense that they decide only whether to apply for credit: no other action, hidden or otherwise, is taken. They all have the same credit requirements, so that market equilibrium involves a pooling outcome in which a given amount of credit is offered on common terms to all entrepreneurs in 
the pool. The terms are determined by a zero expected profit condition that applies, given a competitive banking sector. In this section, we use this pure adverse-selection model as our benchmark, and then consider the various extensions to it.

Even for the benchmark model, the question of the method of finance arises. Whether or not credit contracts involve debt or equity turns out to be relevant for the nature of credit market failure. We begin with a brief discussion of the choice of financing method, although this will be a bit cursory since the issue of business financing would take us too far afield (see Hart, 2001).

\section{Choice of Financing Method}

The original contributions to the credit market failure literature assumed loan contracts, reflecting the reliance that many new firms place on banks for their startup financing. The standard argument for loan contracts is based on asymmetric information with respect to the returns that firms actually obtain from the investments. Williamson (1987) (drawing on Townsend, 1979; Diamond, 1984; and Gale and Hellwig, 1985) shows that if creditors cannot observe the returns of entrepreneurs except at a cost, the equilibrium contract will be a debt contract in which a fixed interest loan is made, and costly ex post monitoring takes place only in the event of a default. Subsequent authors have used variants of this rationale (e.g., de Meza and Webb, 1987), although typically without accounting explicitly for the costly monitoring. Thus, de Meza and Webb (1987) assume that ex post returns in the hands of a firm are unobservable, but in the event of bankruptcy, the bank takes over the firm and learns its returns costlessly.

In the absence of the costly verification of ex post returns, equity contracts can arise in equilibrium in the standard model. Hellmann and Stiglitz (2000) consider the case in which there are competitive markets for both equity and debt finance — so investors in each market 
earn zero expected profits - and entrepreneurs can choose one of the two methods of finance, but not both. If projects can vary both in the probability of success $p$ and in the project return if successful $R$, in equilibrium there will be a cutoff value of $R$ such that among entrepreneurs who apply for project finance, those with returns above the cutoff will opt for debt finance, and all those below will opt for equity finance (Boadway and Keen, 2002). ${ }^{1}$ The intuition is that with loan finance, entrepreneurs obtain all returns above the loan repayment, while those with equity finance only obtain a share. Consequently, high returns are of relatively more value to firms financed with loans, and vice versa for equity.

Once one goes beyond the standard model, other arguments for equity finance come into play (assuming costless ex post verification, of course). When entrepreneurs are more risk averse than lenders, equity contracts can fulfill a risk-pooling function, allowing lenders to bear some of the risk. The risk-pooling function will be tempered to the extent that outcomes depend on unobservable entrepreneurial effort, so there is moral hazard (as in the classic the sharecropping problem). Dewatripont, Legros and Matthews (2002) attempt to resolve this trade-off between risk-pooling and moral hazard by the sequential use of convertible debt and equity. In their model of startup financing, entrepreneurial effort is observable but nonverifiable, and financial contracts can be renegotiated after the effort stage but before the outcome of the project is revealed. They show that, within the class of contracts for which entrepreneurs have limited liability, convertible debt contracts are optimal if the entrepreneur has the renegotiation bargaining power. The possibility of renegotiation allows optimal effort to be induced initially by the use of a debt contract, but then optimal insurance is achieved using

\footnotetext{
${ }^{1}$ The expected return to the entrepreneur with debt finance is $p(R-(1+r) B)$ and that with equity finance is $\sigma p R$, where $B$ is the size of the loan required, $r$ is the interest rate charged by lenders, and $\sigma$ is the entrepreneur's equity share. Since the difference between the expected return with debt finance and that with equity finance is increasing
} 
equity-like claims. This sequence of convertible debt followed by renegotiation to equity circumvents the risk versus moral hazard trade-off.

Recently, attention has been devoted to the allocation of projects between traditional bank financing, involving loans, and venture capital, which typically involves equity contracts. Ueda (2000) models the choice of startup entrepreneurs between bank and venture capital financing when intellectual property rights are not well protected. In contrast to banks, venture capitalists have some technological expertise that allows them to better screen projects, but also to steal the idea and conduct the project without the entrepreneur. In order to receive finance, entrepreneurs must reveal their idea, either to a bank or a venture capitalist. Disclosing the idea to a venture capitalist makes him fully informed about the quality of the project. However, if the entrepreneur chooses bank financing, the bank receives a signal that imperfectly reveals the quality of the project. The choice of financing method reflects a trade-off between the cost of asymmetric information under bank financing, and the threat of expropriation with venture capital. If entrepreneurs have low collateral, they tend to choose venture capital, since banks must charge a higher interest rate for screening purposes. Venture capital is also more attractive when intellectual property rights are better protected, since it reduces the threat of expropriation.

Keuschnigg and Nielsen (2002a) model the allocation of entrepreneurs between bank and venture capital finance as the result of a search and matching process. There are a given number of ex ante identical entrepreneurs and venture capitalists who engage in search with variable search effort. Venture capitalists add value to projects because they have specialized knowledge about particular industries. Entrepreneurs that are unsuccessful in matching with a venture capitalist must resort to traditional bank finance. Following a successful match, the venture

in $R$ (and independent of $p$ ) for given terms of credit, entrepreneurs that opt for debt finance will be those with 
capitalist and the entrepreneur bargain over the terms of an equity contract. Unless the bargaining power of entrepreneurs and venture capitalists are aligned with their matching productivity, their search efforts are inefficient. For example, if the entrepreneurs' relative bargaining power is too high, the search effort of venture capitalists is inefficiently low. Too few financing offers are posted, and the number of deals between venture capitalists and financed entrepreneurs is inefficiently low.

\section{Loan Financing}

In order to study the efficiency consequences of credit market imperfections due to asymmetric information, it is useful to return to the benchmark credit-rationing model with loan financing and zero ex post monitoring costs in the even of bankruptcy. The nature of inefficiency in an adverse selection pooling equilibrium depends on the distribution of firms in the pool. Suppose first that the distribution of firms is uni-dimensional - there is a one-to-one relation between $p$ and $R$. Two classic cases have been studied. In Stiglitz and Weiss (1981), banks are able to differentiate projects by their expected return $p R$, but for a given expected return cannot distinguish riskier (low $p$ ) from less risky projects. Thus, a common rate of interest must apply to all projects with a given expected return. This was contrasted by de Meza and Webb (1987) to the case where banks can classify projects by their returns if successful $R$, but cannot distinguish projects with higher or lower probabilities of success.

The results for these cases are easy to characterize. In either of these two cases, projects can be monotonically ranked by their probability of success $p$. There will therefore be a cutoff value of $p$, say $\widetilde{p}$, that determines the marginal entrepreneur. In the Stiglitz-Weiss case, all projects with p below $\tilde{p}$ — the riskier projects — will be undertaken, while in the de Meza- 
Webb case, all projects with $p$ above $\tilde{p}$ — the higher expected return projects — will be undertaken. Thus, in the Stiglitz-Weiss case, the average probability of success of accepted projects in the pool, $\bar{p}$, will be less than for the marginal project $\tilde{p}$, while the opposite will apply in the de Meza-Webb case. Now, in equilibrium, the marginal project will have a positive social profit if $\widetilde{p}>\bar{p}$, so the number of projects financed is inefficiently low, and vice versa. ${ }^{2}$ That implies that there will be over-investment in the de Meza-Webb case, a situation that can be corrected by a tax on loans, deposits or interest. In the Stiglitz-Weiss case, since expected returns are constant, so are social returns for all projects. If the social return is positive, there will be under-investment, with the highest probability projects not undertaken. On the other hand, if in the Stiglitz-Weiss case no projects should be undertaken, some low probability ones will be: there will be over-investment here.

The results of these two versions of the benchmark model are stark for their polar opposite conclusions about the direction of inefficiency induced by asymmetric information in credit markets. There are a number of ways that the results have been extended, some of which help to resolve the ambiguity about whether too many or too few projects will be funded in equilibrium, and some of which compound it. Some of these extensions are as follows.

Generalized returns. The two special cases considered above involve perfect correlation between the probability of success and the rate of return. In a more general case, projects can take on varying combinations of $p$ and $R$ : there will be a joint distribution of projects over $p$ and $R$. Since banks cannot distinguish projects, they must offer a common interest rate to all

\footnotetext{
${ }^{2}$ More precisely and following Boadway and Keen (2002), firm expected profits are given by $\pi(p, R)=p(R-(1+r) B)$, where $r$ is the interest rate and $B$ is the amount of credit required. Social profits are given by $s(p, R)=p R-(1+\rho) B$, where $\rho$ is the interest rate paid on bank deposits. The zero expected profit condition
} 
projects. Given the interest rate, there will be a spectrum of projects with different $(p, R)$ values that would just give zero net expected profits to entrepreneurs. In Figure 1, taken from Boadway and Keen (2002), the locus of marginal projects is the curve labeled $\pi(p, R)-y=0$, where $y$ is the alternative income of entrepreneurs. All projects to the northeast of this curve, and only those projects, will be undertaken at the given interest rate. There will also be a spectrum of projects involving different $(p, R)$ values that have zero social benefits, labeled $s(p, R)-y=0 .{ }^{3}$ All projects to the northeast of this locus are socially profitable so should be undertaken. As can be seen, some high $R$ - low $p$ projects will be undertaken that should not be, and some low $R-$ high $p$ projects will not be undertaken that should be: there will be over-investment in low $p$ projects and under-investment in high $p$ projects. The reason is that entrepreneurs put relatively low value on a high probability of success since they bear no cost from a bad state. From a policy perspective, a tax policy that taxes low-return projects and subsidizes high-return projects would be called for. To get to the first best, the tax rates would have to differ by project return, which may be difficult to implement.

Credit rationing . Credit rationing (excess demand for loans at the going interest rate) can occur is there is a maximum interest rate that banks will charge. This will be the case if bank profits are maximized at some interest rate, and if the supply of savings is not perfectly elastic. At the maximum interest rate, the demand for loans can exceed the supply that is forthcoming. This can occur in the Stiglitz-Weiss model because bank profits may be decreasing in the interest rate it charges, since a higher interest rate tends to attract entrepreneurs who have a relatively low probability of repayment, but not in the de Meza-Webb case where bank profits always increase

for banks requires $\bar{p}(1+r) B-(1+\rho) B=0$. Using this zero profit condition and the fact that for the marginal project $\pi(\tilde{p}, R)=0$, social profits for the marginal project become $s(\widetilde{p})=(\widetilde{p}-\bar{p})(1+r) B$. 
in the interest rate. The possibility of credit rationing does not, however, affect the policy arguments. There is still the tendency for under-investment as in the Stiglitz-Weiss model without credit rationing, so the case for an interest subsidy remains.

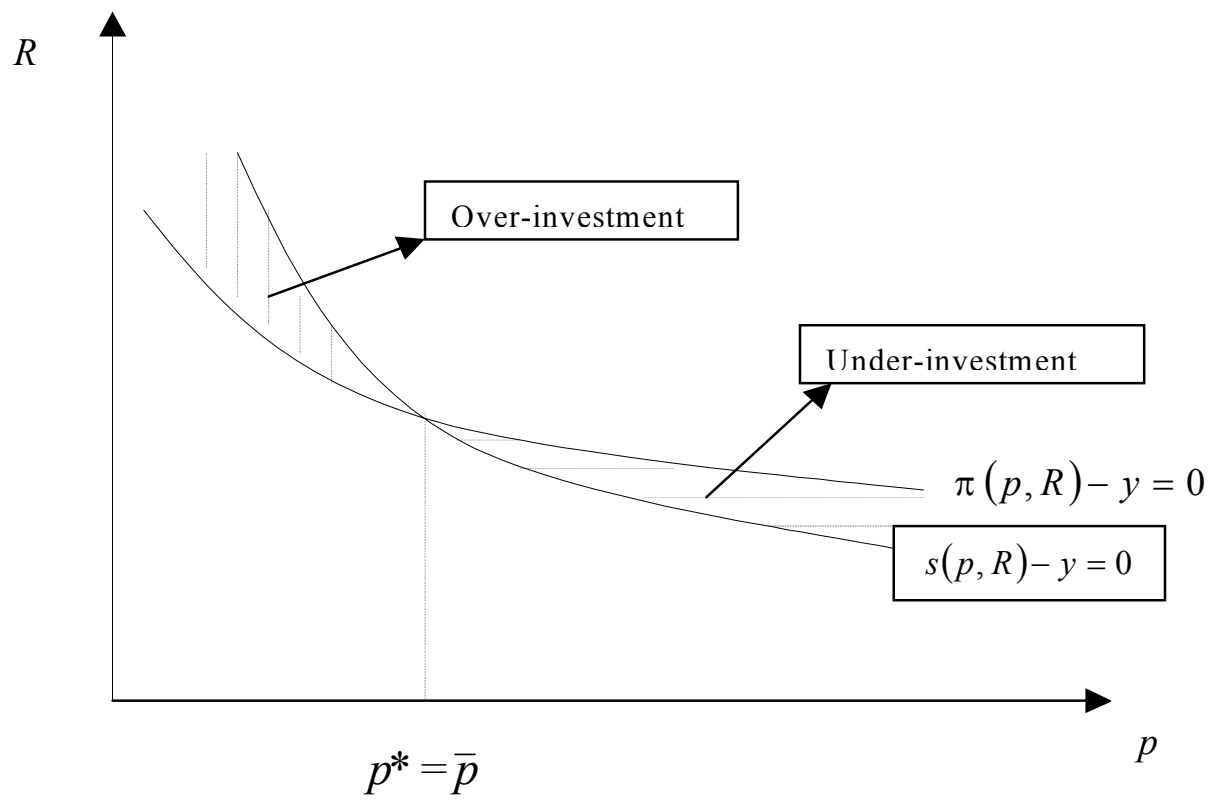

Figure 1

Moral hazard. Suppose entrepreneurs can vary their effort, and that affects their probability of success. If effort is unobservable, in equilibrium there will be too little effort compared with the social optimum. This will not affect the arguments above about too many or too few projects being financed. If the government cannot observe entrepreneurial effort, there may be nothing they can do to improve that. The only possible policy intervention is to subsidize things that are complementary with entrepreneurial effort (or tax those that are substitutes). This is the Arnott and Stiglitz (1986) argument for government policy implications in the face of moral hazard.

Ex post monitoring. Suppose it is costly for banks to monitor projects that declare bankruptcy. This will affect the profits of bank. However, assuming that the cost of monitoring is

\footnotetext{
${ }^{3}$ Recall that $\pi(p, R)=p(R-(1+r) B)$ and $s(p, R)=p R-(1+\rho) B$.
} 
unavoidable even to the government, ex post monitoring costs have, with one exception, no effect on the policy conclusions discussed above (Boadway and Keen, 2002). The exception concerns the Stiglitz-Weiss case where all projects have the same expected returns. Because of the fixed cost of monitoring incurred in the unsuccessful outcome, it is possible that there will be over-investment in low- $p$ projects, that is, those with a larger chance of incurring monitoring costs. Under-investment in high- $p$ projects remains, making the policy implications even more ambiguous.

Ex ante monitoring. Banks may be able to invest resources to obtain information on the probability of project success, and this can allow them to charge different interest rates contingent on the information obtained. Boadway and Sato (1999) study ex ante monitoring for the case where there are only two types of projects: good and bad. The number of projects funded is not an issue since both good and bad projects are worth funding. Monitoring yields an imperfect signal of project profitability, and there can be both type I and type II errors. Entrepreneurs can choose the bank at which to apply for loans, and can change banks after being monitored. It turns out that depending on the type of statistical error associated with monitoring, there can be an inefficient level of monitoring as well as an inefficient choice of interest rate. For example, suppose there are only type II errors, so some bad projects are mistakenly tagged as good ones. In this case, there will be excessive monitoring, and the interest rate charged to highquality projects will be excessive. Given that monitoring effort is unobservable to the government, it will not generally be possible to implement a first-best policy. A second- best one will be a loan guarantee in which the government covers a proportion of the bank loan that is lost in the event of bankruptcy. 
Signaling. As well as banks engaging in monitoring to screen projects, entrepreneurs themselves may be able to signal their quality. Fuest, Huber and Tillessen (2002) assume that entrepreneurs can signal their quality perfectly at a fixed cost to themselves. Unlike in the screening case just considered where the banks bear the monitoring costs, here they are born by the entrepreneurs. In the de Meza-Webb case, it will only pay the highest quality entrepreneurs to incur the cost of signaling themselves. In equilibrium, the entrepreneurs who apply for a loan will segment themselves into a higher $p$ group that chooses to signal and a lower $p$ group that chooses not to. The qualitative result of over-investment remains the same, although the extent of over investment will be reduced. However, because signaling is otherwise unproductive, it is ambiguous whether from a social point of view the benefits of signaling outweigh the costs. In the Stiglitz-Weiss case, all entrepreneurs signal as long as all are socially profitable. Thus, the under-investment is eliminated, but a first-best allocation is not achieved because of the wasteful signaling costs.

Choice of risk. Another form of entrepreneurial decision-making, which is analogous to a form of moral hazard, involves the choice of riskiness of the project. In de Meza and Webb (1999), entrepreneurs vary in ability: those with higher ability produce a higher level of output when the project is successful. Entrepreneurs face a risk-return trade-off. They choose a risk characteristic, which determines the probability of success and the return in the case of success, where the return in the case of success also increases multiplicatively with the ability. There is a unique risk level that maximizes the expected social return for all entrepreneurs. With debt contracts, since entrepreneurs do not bear all the downside risk of their projects, they tend to choose a level of risk higher than optimal, at the expense of expected return. Moreover, more able entrepreneurs choose relatively safer projects. The equilibrium involves pooled-debt 
contracts with high ability entrepreneurs cross-subsidizing low ability ones. Since banks must have zero expected profits in equilibrium, some entrepreneurs with negative expected return receive loans. Therefore, policies that exclude marginal entrepreneurs from the market are welfare improving. A tax on borrowing reduces entry but it increases the deadweight cost of moral hazard by making entrepreneurs take more risk. Therefore, such a tax may increase welfare.

Separating equilibria. In the above models, entrepreneurs differ in only one dimension. If they differ in more than one dimension, things become more complicated. For example entrepreneurs can vary by both probability of success and ability (Boadway, Marceau, Marchand and Vigneault, 1998). Entrepreneurs have a production function involving labor and capital, although labor is not essential for our purposes. (The authors consider also imperfect information in labor markets, to which we return later). They produce output only in a good state. Ability enters as a multiplicative term in the production function, so high-ability entrepreneurs have better production opportunities in the event of success. For any given interest rate, they will demand more capital than low-ability entrepreneurs. In this case, different entrepreneurs will demand different amounts of capital and therefore sizes of loans. As long as there is a one-toone relation between ability and probability of success, this gives rise to a single-crossing property (otherwise we have a multi-dimensional screening problem which can destroy the separating equilibrium). A separating equilibrium can occur whose nature depends upon the relationship between ability and probability of successful outcomes. Banks will therefore be able to charge a higher interest rate to entrepreneurs with a lower probability of success $p$. For example, if higher ability entrepreneurs have higher probability of success, they will face a lower interest rate. However, in order to separate them from the low-ability types, they will have to 
take a larger loan with the lower interest rate thereby distorting their production. Alternatively, if it is the low ability types that have the higher probability of success, their contract will involve a smaller loan than would be efficient. Generally, there will be the efficient number and quality of entrepreneurs who apply for loans, but the outcome will be distorted because of the binding incentive constraints. Tax/subsidy policies can generally improve welfare by relaxing the selfselection constraints. In particular, imposing a tax on the low interest rate loan contracts, whether they are purchased by the high- or the low-ability persons, will improve social benefits (though it will not be Pareto improving).

\section{Equity Financing}

Suppose now that ex post project returns can be observed without cost. In this case, investors could offer either equity or debt contracts. To consider the implications of this, we can adopt the benchmark model to allow for an endogenous choice of financial contract. Suppose, following Hellman and Stiglitz (2000) and as briefly discussed above, that both equity and debt contracts are competitively supplied, and that entrepreneurs may choose to apply for either type of finance. Also, assume that neither credit nor equity rationing occurs.

Figure 2, adopted from Boadway and Keen (2002), depicts equilibrium in the markets for loans and equity finance when entrepreneurs can vary by both return if successful $R$ and probability of success $p$. The locus $\pi^{D}(p, R)-y=0$ shows the $(p, R)$ combinations that would leave entrepreneurs indifferent between applying for loan financing and earning their alternative income $y$. All projects to the northeast of this locus would lead to positive net profits under loan financing. The locus $\pi^{E}(p, R)-y=0$ has the same interpretation for equity finance. If both equity and debt finance are available, all projects to the northeast of the debt zero-profit locus 
and above the return $R$ will chose to be loan-financed, while all those to the northeast of the equity zero-profit locus and below the same $R$ will chose equity finance. ${ }^{4}$ In equilibrium the interest rate of loans and the investors' equity share will adjust so that zero expected profits are earned on their relevant entrepreneurial pools.

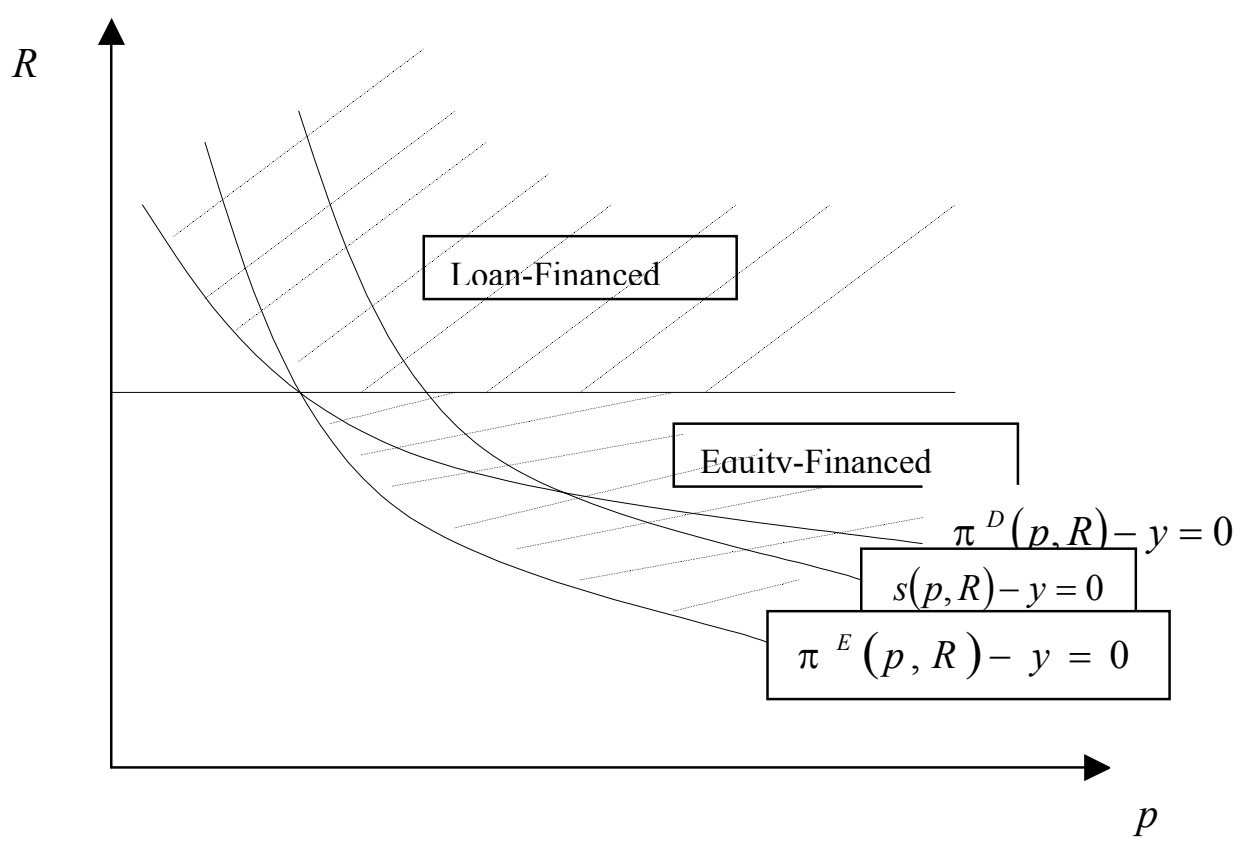

Figure 2

The locus $s(p, R)=0$ indicates the $(p, R)$ combinations that yield zero net social profits.

Like the equity zero-profit locus, it is a rectangular hyperbola with constant expected returns $p R$ at all points. In equilibrium, it lies outside the equity zero-profit locus. ${ }^{5}$ The implication is that

\footnotetext{
${ }^{4}$ These results follow immediately from the fact that $\pi^{D}(p, R)=p(R-(1+r) B)$ and $\pi^{E}(p, R)=\sigma p R$, where $\sigma$ is the entrepreneur's equity share. Differentiation shows that the slope of the loan zero-profit locus is steeper negative than for the equity case. Also, $\pi^{D}(p, R)-\pi^{E}(p, R)$ is increasing in $R$, so for all $R$ above the intersection of the two zero-profit curves, entrepreneurs will prefer loan finance, and vice versa.

${ }^{5}$ The share value is determined by the investors' zero-profit condition, $(1-\sigma) \overline{p R}-(1+\rho) B=0$, where $\overline{p R}$ is the average expected return of projects obtaining equity finance. Let $(p R)^{\pi}=y / \sigma$ be the value of expected profits along the equity zero-profit locus. Substituting for $\sigma$ from the investors' zero-profit expression, we obtain
} 
the social zero-profit locus lies everywhere outside both the loan and the equity zero-profit loci, which implies that there will be over-investment of both loan-financed and equity-financed entrepreneurs. Thus, the ability of investors to offer both loan and equity finance removes the ambiguity about the direction of bias of credit market inefficiency.

Hellmann and Stiglitz (2000) show that in a model similar to the above one with entrepreneurial choice of loan versus equity finance, both credit and equity rationing might occur. Since there would otherwise be over-investment, it is possible that such credit rationing could improve welfare. However, that will not unambiguously be the case since the firms that get rationed out of the market may be socially profitable ones.

\section{Venture Capital Finance}

Venture capitalists (VCs) add an important element to the financing of new entrepreneurs managerial advice that improves the prospects for project success. Given that the level of advice is variable, equity contracts are typically used to provide incentives for optimal VC effort, as well as for the other standard reasons discussed above. To the extent that entrepreneurial effort is also variable, that constrains the form of the contract since incentives must also be provided to entrepreneurs. A common approach is to suppose that VCs have first-mover advantage, acting as a principal to each entrepreneur as their agent. In the simple case where entrepreneurial quality is known so no adverse selection problem arises, the VC designs a contract that elicits optimal effort from the entrepreneur and satisfies the latter's participation constraint. This implies that the entire surplus accrues to the VC.

$(p R)^{\pi}=y+(p R)^{\pi}(1+\rho) B / \overline{p R}<y+(1+\rho) B=(p R)^{s}$, where $(p R)^{s}$ is the expected return along the zero social profits locus. 
This approach is taken in Keuschnigg and Nielsen (2002b), who focus their analysis on the level of managerial advice provided to entrepreneurs by VCs. Entrepreneurial effort is also variable, but since it can only be either high or low, the optimal level can be induced by the contract. They show that the level of managerial advice tends to be too low in equilibrium since the $\mathrm{VC}$ bears the entire cost of his advice but must share the returns with the entrepreneur. Any taxes on project returns, such as a capital gains tax, will further discourage $\mathrm{VC}$ advice. Apart from reducing such taxes, policies that increase the start-up costs faced by VCs will increase their effort by making business failure more costly. Examples include limitations on loss offsets and taxing dividend payments from VCs to their owners.

The same basic model has been extended to a dynamic setting by Tremblay (2002b). Venture capitalists contribute to drastic innovation by providing advice to potential entrepreneurs at the stage of research. Innovation requires $R \& D$ expenditures and effort by entrepreneurs and venture capitalists. For the same reason as above, VCs tend to provide too little innovative effort. In this context, taxing R\&D expenditures increases the VCs effort level.

Keuschnigg (2002) extends this basic model by examining the distortions that arise in the number of projects that VCs choose to support. Because the marginal disutility cost of effort is increasing, the level of advice provided to each entrepreneur decreases as the portfolio of projects grows. At a lower level of advice, the VCs must give entrepreneurs a larger share of profits to satisfy their incentive and participation constraints. The VCs view this as a cost of financing more projects, but from a social perspective it involves only redistribution from VCs to entrepreneurs. Therefore, in equilibrium, both the level of advice and the number of projects financed by venture capitalists tends to be too low. A tax policy that induces the social optimum 
combines tax on start-ups, which raises the level of advice as above, with a revenue subsidy to increase portfolio size.

In addition to moral hazard, problems of adverse selection might also characterize $\mathrm{VC}$ financing. Dietz (2002) introduces the advisory role of VCs in an adverse selection model in which projects have equal expected value in the absence of advice, but differ in their level of risk. Although the advice provided by VCs increases the probability of success $p$ of any project, a given level of advice increases $p$ for riskier (low- $p$ ) projects more than for less risky (high- $p$ ) projects. At the time of contracting, the risk level of projects is unknown to the VCs, so a pooling contract emerges with all VCs offering the same competitive price for VC capital (i.e., the same share of returns). A segmented market equilibrium arises in which the riskier projects choose VC finance, while lower risk ones chooses bank financing, which is cheaper and involves no advice. In a zero-profit equilibrium, too many low-risk projects are financed by VCs because of the usual adverse selection problem associated with pooling contracts.

These inefficiencies provide incentives for screening by VCs. Because of their expertise, VCs are usually seen as having higher screening abilities than banks. Kanniainen and Leppämäki (2002) examine the entry of entrepreneurs with different talent levels in human capital-intensive industries and in conventional industries. There is a continuum of talent levels. There is a cut-off level of talent above which expected return is higher in the human capital industry. So highly talented entrepreneur go to the human capital sector. Investors are unable to observe talent, so in the absence of screening there is too much entry of entrepreneurs into both industries under bank financing. VCs can identify an entrepreneur's talent perfectly, but at a fixed screening cost, which is borne implicitly by entrepreneurs in equilibrium. In equilibrium, the most talented people in the human capital sector get VC financing and are screened. The lower talent people in 
the human capital sector (who have more talent than those in the conventional sector) get bank financing. The lowest talent entrepreneurs choose the conventional sector. Even lower talented people choose employment. Since the presence of VCs raises the marginal talent level that enters into the human capital-intensive industry, it also transfers some relatively talented entrepreneurs into the conventional industry. In turn, that tends to increase the profitability of uninformed finance, which leads banks to provide financing at lower costs to all applicants in the conventional industry. Hence, additional lower talent individuals also choose to enter. Therefore, though efficiency may be enhanced in the human capital industries by VC finance, the effect on total welfare is ambiguous (as in Fuest, Huber and Tillessen, 2000).

To summarize this section on financing, asymmetric information in credit markets seems to lead, if anything, to excessive entry by new firms rather than too little. This makes policy implications ambiguous since the upshot of earlier sections was that new firms might well find themselves at a disadvantage relative to incumbents because of barriers to entry, tax policy, and so on. The final section considers a further set of issues that tends to work to the disadvantage of small firms, those arising from labor market imperfections.

\section{Labor Market Issues}

Startup firms may face problems in hiring workers that put them at a disadvantage with respect to established firms. To the extent that these reflect market imperfections, government policy might be able to improve welfare. The following are examples of this. 


\section{Adverse Selection}

Analogous to the case of credit market information asymmetries where banks cannot tell good projects from bad ones, firms in an industry may not be able to tell good workers — those with higher productivities — from bad ones when they initially hire them. The result is that the same wage must be applied to all workers regardless of their quality (Weiss, 1980). Profitmaximizing competitive firms will hire workers until the value of the marginal product of the average worker just equals the wage rate, where the wage rate reflects the workers' value elsewhere in the economy (where asymmetric information does not apply). The marginal worker is of higher quality than the average worker in the hiring pool, so will have a higher marginal product that the wage paid. Because of this adverse selection, too few workers will be hired from a social point of view, so wage subsidy to this industry would be welfare improving. (In fact, as Weiss argues, there may be excess demand in equilibrium: there may be a minimum wage that firms will offer since lowering the wage attracts lower quality workers). This kind of adverse selection problem may be more important for startup firms than for established ones since they are hiring workers for the first time and so have not yet had a chance to learn workers' skills. In this case, a preferential wage subsidy to startup firms could improve welfare.

\section{Search Externalities}

There may be inefficiencies associated with entry in search models of the labor market (Diamond, 1982a). In these models, the probability of creating a job match depends on the unemployment and vacancy rates. Following a match, the worker and the firm bargain over the wage rate. The threat point of each party determines the outcome of bargaining, where the threat points of the worker and the firm depend on the expected value of waiting for the next match with another job or another worker, respectively. If the unemployment rate is high, the threat 
point of the worker is weak relative to that of the firm, and vice-versa when the vacancy rate is high. The search process involves externalities: an additional worker searching for a match lowers the probability of other workers finding a job, but makes it more likely for vacancies to be filled. Similarly, posting a vacancy increases the matching probability of workers but decreases that of other vacancies. The incentive to enter the labor market and to create vacancies are distorted relative to the social optimum, since the wage that results from relative bargaining powers does not reflect in general the balance of search externalities. If the effectiveness of new firms in the search process is low relative to that of established firms, they will be disadvantaged in two ways. First, they will have a lower probability of finding and keeping a match, and second, their threat point, when they do find a match, will be relatively weak since the expected value of waiting for the next match will be low. So new firms would have to post more vacancies than established firms to find a given number of matches and would pay higher wages as a result of the bargaining process.

Job matching may also be relevant in a dynamic setting. If the labor reallocation required by the entry of innovating firms in production is subject to a matching process, creative destruction will result in long-run unemployment, as shown by Aghion and Howitt (1994). A higher growth rate affects the equilibrium rate of unemployment through two competing effects. On one hand, a higher growth rate increases the capitalized returns from creating vacancies, which tends to lower the unemployment rate. On the other hand, a higher growth rate increases equilibrium unemployment both directly by increasing the job separation rate, and indirectly by reducing the lifetime of firms, which in turn lowers the incentives for firms to enter and create vacancies. In this context, because firms do not take into account the impact of their R\&D 
decisions on the labor market, the speed of innovation and the rate of entry in the market may be socially inefficient.

\section{Efficiency Wages}

Labor market inefficiencies can also arise because of hidden action on the part of workers. In efficiency wage models, firms in industries where shirking is difficult to detect must offer wages in excess of market clearing levels (Shapiro and Stiglitz, 1984). Since the marginal worker hired produces more than their next best alternative, a wage subsidy will be welfare improving. Unobserved worker effort might also be a particularly relevant problem for startup firms. Their employees are newer and less known to the firm, and good monitoring technologies may not have been developed. In these circumstances, an incentive for new firms to hire workers could improve efficiency.

\section{Human Capital Investment}

Firms need to invest in the human capital of their employees in order to produce efficiently. Startup firms may find such investment more difficult to do. Human capital investment requires financing, and they may find it more difficult to obtain the financing since they must rely on outside sources and cannot use human capital as collateral. And because they do not know the skills of their workers well, they may find it difficult to know in which ones they should invest.

\section{Employee Benefits}

Finally, part of the compensation package of firms consists of employee benefits (pensions, supplementary health care, disability insurance, etc.). Firms provide these partly because they can exercise bargaining power with insurers, and partly because they can obtain a commitment 
from insurers to provide long-term coverage. Startup firms may find these difficult to provide to their employees with the result that it is more costly for them to hire employees.

\section{Conclusions}

In this paper, we have outlined the potential sources of market failure that might apply to startup entrepreneurs. The latter can be particularly prone to market failures because of the innovative and novel nature of the activities in which they presumably engage. To the extent that market failures exist, they can lead to inefficient choices by entrepreneurs in various dimensions, such as the level of innovative activity, the decision to enter an industry, and the investment, production and employment decisions once they have entered. More generally, market outcomes can be inefficient because investors provide non-optimal levels and types of financing, as well as perhaps undertaking inefficient levels of monitoring or screening and providing inadequate levels of managerial advice.

The types of market failure are diverse. They can include externalities arising from the innovative activity of new firms, especially relative to existing firms. The fact that startup entrepreneurs are often engaged in activities that are not perfectly competitive implies that strategic behavior can be important and can preclude social benefits from being fully exploited. The characteristics of potential startup firms may not be publicly observable, and this can give rise to inefficiencies of asymmetric information, especially with respect to their financing. Government tax policies themselves might put startup firms at a disadvantage, especially given their reliance on outside finance and the fact that their cash flows are likely to be initially negative and ultimately uncertain. And, there may simply be coordination failures, such as those applying in frictional labor markets, which are particularly relevant for startup firms. 
To the extent that market failures exist, there ought in principle to be a role for public policy. In some cases, such roles can be readily identified and policy prescriptions recommended. Thus, the tendency for capital markets to extend credit at excessively favorable terms in the presence of adverse selection — which we have suggested might generally be the case - can be addressed by selective tax policies. Or, the fact that certain features of the tax system — the absence of refundability provisions, the treatment of dividends, etc. — can be addressed by appropriate policy reforms.

But at the same time, a couple of important caveats need to be borne in mind before offering definitive policy advice. First, in cataloguing the various instances of market failure, it was frequently the case that the direction of the distortionary effect was not clear. For example, there may have been offsetting effects whose relative magnitudes were ambiguous. Second, not all disadvantages that startup entrepreneurs face represent market failures. They may simply face high initial investment costs; they may lack commercial experience and expertise; they may have limited access to certain technologies; and they may lack collateral. If the special problems that startup firms face do not reflect market failure, it would be inappropriate on efficiency grounds to recommend policy intervention.

Nonetheless, we have identified a number of instances of market failure, and subject to the above caveats, we can provide some tentative policy implications. The policies will, of course, depend on the nature and direction of the distortion and on the type of decision leading to the inefficiency: research, entry, capital investment, financing, exit, labor market decisions, etc. Since many of the distortions apply to new firms, policies may also need to distinguish startup entrepreneurs from established firms. 
To be more precise, the following tentative policy conclusions can be drawn on the basis of our current reading of the literature:

- Innovation decisions are likely to be distorted in opposite directions for new firms, so it is generally ambiguous whether policy should encourage or discourage R\&D. However, it can be argued that new firms should not be treated more favorably than existing firms: if anything, the opposite, since the business-stealing effect applies to them and not to established firms.

- Entry deterrence motives may lead established firms to over-invest, and to take other measures that discourage entry, such as advertising or excessive patenting: policies that discourage excessive capacity accumulation, advertising or patenting may be efficiency enhancing.

- Business tax systems can discriminate against new entrepreneurs to the extent that they discourage risk and discriminate against outside finance. Both these problems can be addressed by fully refundable tax systems. More generally, differential tax treatment of unincorporated firms and small corporations should be eliminated where it exists.

- Adverse selection on credit markets generally tends to lead to excessive entry by new entrepreneurs, and that will be unambiguously the case if both debt and equity finance are competitively available. Thus, a tax on loans or deposits would be welfare improving.

- Imperfections in the labor market may particularly apply to new firms and may result in them hiring too few workers. Wage subsidies targeted at new firms would improve efficiency in this case. 


\section{References}

Aghion, P. and P. Howitt (1992), 'A Model of Growth Through Creative Destruction,' Econometrica 60, 323-351.

Aghion, P. and P. Howitt (1994), 'Growth and Unemployment,' Review of Economic Studies 61, 477-494.

Alexander-Cook, K., D. Bernhardt and J. Roberts (1998), 'Riding Free on the Signals of Others,' Journal of Public Economics 67, 25-43.

Arnott, R.J. and J.E. Stiglitz (1986), 'Moral Hazard and Optimal Commodity Taxation,' Journal of Public Economics 29, 1-24.

Arrow, K. (1962a), 'Economic Welfare and the Allocation of Resources for Invention,' in The Rate and Direction of Inventive Activity, ed. R. Nelson, Princeton University Press.

Arrow, K. (1962b), 'The Economic Implications of Learning by Doing,' Review of Economic Studies 29, 155-173.

Atkinson, A. and J. Stiglitz (1969), 'A New View of Technological Change,' The Economic Journal, 573-578.

Auerbach, A.J. (1983), 'Taxation, Corporate Financial Policy and the Cost of Capital,' Journal of Economic Literature XXI, 905-940.

Baldani, J. and R. Masson (1984), 'Economics of Scale, Strategic Advertising, and Fully Credible Entry Deterrence,' Review of Industrial Organization 1, 190-205.

Berry Cullen, J. and R. Gordon (2002), 'Taxes and Entrepreneurial Activity: Theory and Evidence for the U.S.,' mimeo.

Boadway, R. and M. Keen (2002), 'Imperfect Information and Public Intervention in Credit Markets,' mimeo.

Boadway, R. and M. Sato (1999), 'Information Acquisition and Government Intervention in Credit Markets,' Journal of Public Economic Theory 1, 283-308.

Boadway, R., M. Marchand and P. Pestieau (1991), 'Optimal Linear Income Taxation in Models with Occupational Choice,' Journal of Public Economics 46, 133-162.

Boadway, R., N. Marceau, M. Marchand and M. Vigneault (1998), 'Entrepreneurship, Asymmetric Information, and Unemployment,' International Tax and Public Finance 5, $307-27$.

Dasgupta, P. and J. Stiglitz (1980), 'Uncertainty, Industrial Structure and the Speed of R\&D,' Bell Journal of Economics 11, 1-28.

de Meza, D. and D.C. Webb (1987), 'Too Much Investment: A Problem of Asymmetric Information,' Quarterly Journal of Economics 102, 281-92.

de Meza, D. and D.C. Webb (1999), 'Wealth, Enterprise and Credit Policy,' The Economic Journal 109, 153-63. 
de Meza, D. and D.C. Webb (2000), 'Does Credit Rationing Imply Insufficient Lending,' Journal of Public Economics 78, 215-34.

Dewatripont, M., P. Legros and S. Matthews (2002), 'Moral Hazard and Capital Structure Dynamics,' CEPR Discussion Paper 3487.

Diamond, D. (1984), 'Financial Intermediation and Delegated Monitoring,' Review of Economic Studies 51, 393-414.

Diamond, P. (1982a), 'Wage Determination and Efficiency in Search Equilibrium,' Review of Economic Studies 49, 217-227.

Diamond, P.A. (1982b), 'Aggregate Demand Management in Search Equilibrium,' Journal of Political Economy 90, 881-894.

Dietz, M. (2002), 'Risk, Self Selection, and Advice: Banks versus Venture Capitalists,' University of St. Gallen.

Dixit, A. (1980), 'The Role of Investment in Entry Deterrence,' Economic Journal 90, 95-106.

Dixit, A. and J. Stiglitz (1977), 'Monopolistic Competition and Optimum Product Diversity,' American Economic Review 67, 297-308.

Eaton, C. and R. Lipsey (1981), 'Capital, Commitment, and Entry Equilibrium,' Bell Journal of Economics 12, 593-604.

Fudenberg, D. and J. Tirole (1983), 'Capital as a Commitment: Strategic Investment to Deter Mobility,' Journal of Economic Theory 31, 227-250.

Fuest, C, B. Huber and P. Tillessen (2002), 'Tax Policy and Entrepreneurship in the Presence of Asymmetric Information in Capital Markets,' mimeo.

Fujita, M. and J.F. Thisse (2001), 'Agglomeration and Market Interaction,' mimeo.

Futia, C. (1980), 'Schumpeterian Competition,' Quarterly Journal of Economics 93, 675-695.

Gale, D. and M. Hellwig (1985), 'Incentive-Compatible Debt Contracts: The One-Period Problem,' Review of Economic Studies 52, 647-664.

Gans, J., D. Hsu and S. Stern (2002), 'When Does Start-up Innovation Spur the Gale of Creative Destruction?,' Rand Journal of Economics, forthcoming.

Gentry, W. and G. Hubbard (2001), 'Tax Policy and Entry into Entrepreneurship,' mimeo.

Gilbert, R. and D. Newbery (1982), 'Preemptive Patenting and the Persistence of Monopoly,' American Economic Review 72, 514-526.

Gordon, R. (1998), 'Can High Personal Tax Rates Encourage Entrepreneurial Activity?,' IMF Staff Papers 45, 49-80.

Grossman, G. and C. Shapiro (1984), 'Informative Advertising with Differentiated Products,' Review of Economic Studies 51, 63-82.

Hart, O. (2001), 'Financial Contracting,' Journal of Economic Literature XXXIX, 1079-1100.

Hellmann, T. and J, Stiglitz (2000), 'Credit and Equity Rationing in Markets with Adverse Selection,' European Economic Review 44, 281-304. 
Jaffee, D. and T. Russell (1976), 'Imperfect Information and Credit Rationing,' Quarterly Journal of Economics 90, 651-66.

Jovanovich, B. and S. Lach (1989), 'Entry, Exit, and Diffusion with Learning by Doing,' American Economic Review 79, 690-699.

Kaldor, N. and J. Mirrlees (1962), 'A New Model of Economic Growth,' Review of Economic Studies, 174-192.

Kanniainen, V. and M. Leppämäki (2002), 'Financial Institutions and the Allocation of Talent,' Bank of Finland Discussion Paper no.5.

Kennedy, C. (1964), 'Induced Bias in Innovation and the Theory of Distribution,' The Economic Journal, 541-547.

Keuschnigg, C. (2002), 'Taxation of a Venture Capitalist with a Portfolio of Firms,' University of St-Gallen.

Keuschnigg, C. and S.B. Neilsen (2002a), 'Public Policy for Startup Entrepreneurship with Venture Capital and Bank Finance,' mimeo.

Keuschnigg, C. and S.B. Neilsen (2002b), 'Tax Policy, Venture Capital, and Entrepreneurship,' Journal of Public Economics, forthcoming.

Marceau, N. and M. Smart (2002), 'Corporate Lobbying and Commitment Failure in Capital Taxation', American Economic Review, forthcoming.

Ottaviano, G. and J.F. Thisse (2000), 'On Economic Geography in Economic Theory: Increasing Returns and Pecuniary Externalities,' Journal of Economic Geography, Forthcoming.

Reinganum, J. (1983), 'Uncertain Innovation and the Persistence of Monopoly,' American Economic Review 73, 741-748.

Reinganum, J. (1985), 'Innovation and Industry Evolution,' Quarterly Journal of Economics, 8199.

Rogerson, W. (1982), 'The Social Cost of Regulation and Monopoly: A Game-Theoretic Analysis,' Bell Journal of Economics 13, 391-401.

Romer, P. (1986), 'Increasing Returns and Long-Run Growth,' Journal of Political Economy 94, 1002-1037.

Romer, P. (1990), 'Endogenous Technological Change,' Journal of Political Economy 98, S71S102.

Rosen, H. (2002), 'Entrepreneurship and Taxation: Empirical Evidence,' mimeo.

Salop, S. (1979), 'Monopolistic Competition with Outside Goods,' Bell Journal of Economics 10, 141-156.

Schmalensee, R. (1983), 'Advertising and Entry Deterrence: An Exploratory Model,' Journal of Political Economy 91, 636-653.

Schumpeter, J. (1942), Capitalism, Socialism and Democracy (New York: Harper and Row).

Shapiro, C. and J.E. Stiglitz (1984), 'Equilibrium Unemployment as a Worker Discipline Device,' American Economic Review 74, 433-44. 
Soubeyran, A. and J.F. Thisse (1999), 'Learning-by-Doing and the Development of Industrial Districts,' Journal of Urban Economics 45, 156-176.

Spence, M. (1976), 'Product Selection, Fixed Costs and Monopolistic Competition,' Review of Economic Studies 43, 217-235.

Spence, A. (1977), 'Entry, Capacity, Investment and Oligopolistic Pricing,' Bell Journal of Economics 8, 534-544.

Stiglitz, J.E. and A. Weiss (1981), 'Credit Rationing in Markets with Imperfect Information,' American Economic Review 71, 393-410.

Stiglitz, J.E. and A. Weiss (1983), 'Incentive Effects of Terminations: Applications to the Credit and Labor Markets,' American Economic Review 73, 912-27.

Townsend, R. (1979), 'Optimal Contracts and Competitive Markets with Costly State Verification,' Journal of Economic Theory 21, 265-293.

Tremblay, J.F. (2002a), 'Taxation and Technology Adoption in the Presence of Strategic Investment,' Queen's University.

Tremblay, J.F. (2002b), ‘Taxation and Innovation with Venture Capital Financing,' Queen's University.

Ueda, M. (2000), ‘Bank Versus Venture Capital’, Universitat Pompeu Fabra.

Vigneault, M. (1996), 'Commitment and the Time Structure of Foreign Direct Investment,' International Tax and Public Finance 3, 479-494.

Webb, D.C. (2000), 'The Impact of Liquidity Constraints on Bank Lending Policy,' The Economic Journal 110, 169-91.

Weiss, A. (1980), 'Job Queues and Layoffs in Labor Markets with Flexible Wages,' Journal of Political Economy 88, 526-538.

Wen, J-F. (1997), 'Tax Holidays and the International Capital Market,' International Tax and Public Finance 4, 129-148.

Williamson, S. (1986), 'Costly Monitoring, Financial Intermediation and Equilibrium Credit Rationing,' Journal of Monetary Economics 18, 159-79.

Williamson, S. (1987), 'Costly Monitoring, Loan Contracts, and Equilibrium Credit Rationing,' Quarterly Journal of Economics 101, 135-45. 


\title{
CESifo Working Paper Series
}

\author{
(for full list see www.cesifo.de)
}

812 Stéphanie Stolz, Banking Supervision in Integrated Financial Markets: Implications for the EU, December 2002

813 Christian Keuschnigg, Taxation of a Venture Capitalist with a Portfolio of Firms, December 2002

814 Inés Macho-Stadler and David Pérez-Castrillo, Settlement in Tax Evasion Prosecution, December 2002

815 Rainer Niemann and Dirk Simons, Costs, Benefits, and Tax-induced Distortions of Stock Option Plans, December 2002

816 Jan-Egbert Sturm and Barry Williams, Deregulation, Entry of Foreign Banks and Bank Efficiency in Australia, December 2002

817 V. Anton Muscatelli, Patrizio Tirelli, and Carmine Trecroci, Monetary and Fiscal Policy Interactions over the Cycle: Some Empirical Evidence, December 2002

818 Claude Hillinger, A General Theory of Price and Quantity Aggregation and Welfare Measurement, December 2002

819 Erkki Koskela and Ronnie Schöb, Optimal Capital Taxation in Economies with Unionised and Competitive Labour Markets, December 2002

820 Sheilagh Ogilvie, Guilds, Efficiency, and Social Capital: Evidence from German ProtoIndustry, December 2002

821 Hans Gersbach and Verena Liessem, Financing Democracy, December 2002

822 Costas Hadjiyiannis, Panos Hatzipanayotou, and Michael S. Michael, Optimal Tax Policies with Private-Public Clean-Up, Cross-Border Pollution and Capital Mobility, December 2002

823 François Ortalo-Magné and Sven Rady, Homeownership: Low Household Mobility, Volatile Housing Prices, High Income Dispersion, December 2002

824 Syed M. Ahsan and Panagiotis Tsigaris, Measuring the Social Discount Rate under Uncertainty: A Methodology and Application, December 2002

825 Kai A. Konrad, Altruism and Envy in Contests: An Evolutionarily Stable Symbiosis, December 2002 
826 Robert S. Chirinko and Huntley Schaller, A Revealed Preference Approach to Understanding Corporate Governance Problems: Evidence from Canada, December 2002

827 Geir B. Asheim, Green National Accounting for Welfare and Sustainability: A Taxonomy of Assumptions and Results, December 2002

828 Andrea Gebauer, Chang Woon Nam, and Rüdiger Parsche, Lessons of the 1999 Abolition of Intra-EU Duty Free Sales for Eastern European EU Candidates, December 2002

829 Giacomo Corneo, Work and Television, December 2002

830 Vivek H. Dehejia and Yiagadeesen Samy, Trade and Labour Standards - Theory, New Empirical Evidence, and Policy Implications, December 2002

831 Geir B. Asheim and Wolfgang Buchholz, A General Approach to Welfare Measurement through National Income Accounting, December 2002

832 Aaron Tornell and Frank Westermann, The Credit Channel in Middle Income Countries, January 2003

833 Gebhard Flaig, Time Series Properties of the German Monthly Production Index, January 2003

834 Campbell Leith and Jim Malley, Estimated Open Economy New Keynesian Phillips Curves for the G7, January 2003

835 Burkhard Heer and Bernd Süssmuth, Inflation and Wealth Distribution, January 2003

836 Erkki Koskela and Leopold von Thadden, Optimal Factor Taxation under Wage Bargaining - A Dynamic Perspective, January 2003

837 Carola Grün and Stephan Klasen, Growth, Income Distribution, and Well-Being: Comparisons across Space and Time, January 2003

838 Robert S. Chirinko and Ulf von Kalckreuth, On the German Monetary Transmission Mechanism: Interest Rate and Credit Channels for Investment Spending, January 2003

839 Sascha O. Becker, Andrea Ichino, and Giovanni Peri, How Large is the "Brain Drain" from Italy?", January 2003

840 Albert Berry and John Serieux, All About the Giants: Probing the Influences on Growth and Income Inequality at the End of the $20^{\text {th }}$ Century, January 2003

841 Robert Fenge and Martin Werding, Ageing and the Tax Implied in Public Pension Schemes: Simulations for Selected OECD Countries, January 2003

842 Robert Fenge and Martin Werding, Ageing and Fiscal Imbalances Across Generations: Concepts of Measurement, January 2003 
843 Giovanni Andrea Cornia, The Impact of Liberalisation and Globalisation on Income Inequality in Developing and Transitional Economies, January 2003

844 Peter Fredriksson and Per Johansson, Program Evaluation and Random Program Starts, January 2003

845 Bernd Hayo and Matthias Wrede, Fiscal Equalisation: Principles and an Application to the European Union, January 2003

846 Syed M. Ahsan and Jaideep Oberoi, Inequality, Well-being and Institutions in Latin America and the Caribbean, January 2003

847 Chang Woon Nam and Doina Maria Radulescu, The Role of Tax Depreciation for Investment Decisions: A Comparison of European Transition Countries, January 2003

848 V. Bhaskar and Steinar Holden, Wage Differentiation via Subsidised General Training, January 2003

849 Paloma Lopez-Garcia, Labour Market Performance and Start-up Costs: OECD Evidence, January 2003

850 Christian Keuschnigg and Soren Bo Nielsen, Public Policy for Start-up Entrepreneurship with Venture Capital and Bank Finance, January 2003

851 Yin-Wong Cheung, Menzie D. Chinn, and Eiji Fujii, China, Hong Kong, and Taiwan: A Quantitative Assessment of Real and Financial Integration, January 2003

852 Gregory D. Hess, The Economic Welfare Cost of Conflict: An Empirical Assessment, February 2003

853 Douglas J. Cumming and Jeffrey G. MacIntosh, Comparative Venture Capital Governance. Private versus Labour Sponsored Venture Capital Funds, February 2003

854 Eckhard Janeba and John Douglas Wilson, Decentralization and International Tax Competition, February 2003

855 Tapio Palokangas, Capital Accumulation and Employment Cycles in a Model of Creative Destruction, February 2003

856 Brendan Walsh, When Unemployment Disappears: Ireland in the 1990s, February 2003

857 Luis H. R. Alvarez and Erkki Koskela, A General Approach to the Stochastic Rotation Problem with Amenity Valuation, February 2003

858 Christian Schultz, Strategic Campaigns and Redistributive Politics, February 2003

859 Ernst Fehr and Joseph Henrich, Is Strong Reciprocity a Maladaptation? On the Evolutionary Foundations of Human Altruism, February 2003

860 Haizhou Huang, Dalia Marin, and Chenggang Xu, Financial Crisis, Economic Recovery and Banking Development in Former Soviet Union Economies, February 2003 
861 Pedro Cardoso and Bernard M.S. van Praag, How Sustainable Are Old-age Pensions in a Shrinking Population with Endogenous Labour Supply?, February 2003

862 Volker Meier, Efficient Transfer of Aging Provisions in Private Health Insurance, February 2003

863 Edward Castronova, Theory of the Avatar, February 2003

864 Robert S. Chirinko, Hans van Ees, Harry Garretsen, and Elmer Sterken, Investor Protections and Concentrated Ownership: Assessing Corporate Control Mechanisms in the Netherlands, February 2003

865 Bernard M.S. van Praag and Pedro Cardoso, The Mix Between Pay-as-you-go and Funded Pensions and what Demography has to do with it, February 2003

866 Ernst Fehr, Urs Fischbacher, Bernhard von Rosenbladt, Jürgen Schupp, and Gert G. Wagner, A Nation-Wide Laboratory. Examining Trust and Trustworthiness by Integrating Behavioral Experiments into Representative Survey, February 2003

867 Frank Heinemann, The Inflationary Impact of Wage Indexation, February 2003

868 Eytan Sheshinski, Bounded Rationality and Socially Optimal Limits on Choice in a Self-Selection Model, February 2003

869 M. Hashem Pesaran, Estimation and Inference in Large Heterogenous Panels with Cross Section Dependence, February 2003

870 Luis H. R. Alvarez and Erkki Koskela, On the Tree-Cutting Problem under Interest Rate and Forest Value Uncertainty, February 2003

871 Norbert Berthold and Rainer Fehn, Unemployment in Germany: Reasons and Remedies, February 2003

872 Clemens Fuest, Bernd Huber, and Philipp Tilleßen, Tax Policy and Entrepreneurship in the Presence of Asymmetric Information in Capital Markets, February 2003

873 Eytan Sheshinski, Optimum and Risk-Class Pricing of Annuities, February 2003

874 Willi Leibfritz, Paul O'Brien and Jean-Christophe Dumont, Effects of Immigration on Labour Markets and Government Budgets - An Overview, February 2003

875 M. Hashem Pesaran and Allan Timmermann, How Costly is it to Ignore Breaks when Forecasting the Direction of a Time Series?, February 2003

876 Thorvaldur Gylfason and Gylfi Zoega, Education, Social Equality and Economic Growth: A View of the Landscape, February 2003

877 Robin Boadway and Jean-François Tremblay, Public Economics and Startup Entrepreneurs, February 2003 